\title{
Prevalence of Phenylthiocarbamide (PTC) Taste Sensitivity and Colour Blindness in Tengger Tribe Population, Ranupani Village, Senduro, Lumajang
}

\author{
(Prevalensi Kemampuan Mengecap Pheny/thiocarbamide (PTC) dan Buta Warna pada \\ Populasi Suku Tengger, Desa Ranupani, Senduro, Lumajang) \\ Rike Oktarianti*), Iguh Widigda Putra, Resmining Mega Arofa, Asmoro Lelono \\ Jurusan Biologi, Fakultas Matematika dan Ilmu Pengetabuan Alam, Universitas Jember
}

Jn. Kalimantan 37, Jember 68121

\section{ABSTRACT}

The taste of sensitivity of phenylthiocarbamide (PTC), is autosomal dominant trait inherited while the colour blindness is a sex linked genetic trait on the $\mathrm{X}$ chromosome. The purpose of this study was to determine the distribution of taster and non taster phenotypes, prevalence of color blindness, frequency of taster and non taster alleles, and frequency of color blind alleles, as well as pedigree analysis in non taster and color blind families. The research was conducted on the Tengger tribe, in Ranupani village, Senduro, Lumajang. Determination of the sample is carryout randomly. Detection of the ability to taste PTC was respondents to taste the PTC solution from the lowest concentration of $0.32 \mathrm{mg} / \mathrm{L}$ (P13) to the highest concentration of 1300 mg/L (P1). Color blindness detection by the Ishihara method. The results of the study showed that the distribution of the taster was $98.1 \%$ while the non-taster was $1.9 \%$. The allele frequency of the dominant taster $(\mathrm{T})$ was 0.86 and the recessive allele non taster $(\mathrm{t})$ is 0.14 . The prevalence of color blindness in the population of the Tengger tribe was $0.63 \%$ and the allele frequency for color blindness was 0.013 . The pedigree analysis of non taster family showed that non taster individuals were born from taster couple ( $\mathrm{Tt}$ ) or from couple of non taster (tt) with tasters $(\mathrm{Tt})$ heterozigot. While the pattern of inheritance of color blindness was criss-cross inheritance pattern, which is passed from mother to son.

Kemampuan mengecap rasa pahit Phenylthiocarbamide (PTC) merupakan pewarisan autosomal sedangkan buta warna adalah kelainan genetik yang disebabkan oleh gen terangkai kromosom kelamin X. Tujuan dari penelitian ini adalah untuk mengetahui distribusi fenotip taster, non taster, prevalensi buta warna serta frekuensi alel baik taster, non taster dan buta warna. Selain itu juga melakukan analisis pedigree terhadap keluarga non taster dan buta warna. Pengambilan sampel dilakukan pada suku Tengger, di desa Ranupani, kecamatan Senduro, kabupaten Lumajang. Penentuan sampel dilakukan secara acak. Deteksi kemampuan mengecap PTC dilakukan dengan cara responden diminta merasakan larutan PTC. Larutan PTC yang digunakan adalah dari konsentrasi terendah 0,32mg/L (P13) hingga konsentrasi tertinggi $1300 \mathrm{mg} / \mathrm{L}$ (P1). Deteksi kelainan buta warna dilakukan dengan metode Ishihara. Hasil penelitian terhadap kemampuan mengecap PTC pada suku Tengger menunjukan distribusi fenotip taster sebesar 98,1 \% sedangkan non taster sebesar 1,9\%. Nilai frekuensi alel dominan taster (T) sebesar 0,86 dan alel resesif $(\mathrm{t})$ non taster sebesar 0,14 . Prevalensi buta warna pada populasi suku Tengger di Desa Ranupani adalah sebesar 0,63\% dan frekuensi alel buta warna sebesar 0,013. Hasil analisis pedigree menunjukkan bahwa individu non taster yang ditemukan pada populasi suku Tengger dilahirkan dari pasangan taster heterozigot ( $\mathrm{Tt}$ ) atau dari hasil perkawinan non taster ( $\mathrm{tt}$ ) dengan taster heterozigotik ( $\mathrm{Tt}$ ). Sedangkan pola pewarisan buta warna menunjukkan pola pewarisan bersilang yaitu diwariskan dari ibu ke anak laki-laki.

Keywords: Phenylthiocarbamida (PTC), colour blindness, Tengger tribe.

*)Corresponding author:

Rike Oktarianti

E-mail: rike.fmipa@unej.ac.id

\section{PENDAHULUAN}

Masyarakat suku Tengger merupakan komunitas adat atau suku yang mendiami kawasan Taman
Nasional Bromo Tengger Semeru (TNBTS) [1]. Masyarakat suku Tengger merupakan salah satu suku yang masih mempertahankan nilai - nilai dan budaya lokal ditengah gempuran modernisasi [2]. Perkawinan 
masyarakat Tengger terjadi antara kalangan masyarakat Tengger sendiri (endogami). Endogami pada masyarakat Tengger tergolong dalam endogami lokal yakni perkawinan antar desa pada wilayah Tengger sendiri, diantaranya juga ada yang melakukan perkawinan antar kerabat [3]. Dampak perkawinan endogami adalah meningkatkan homosigositas dan menurunkan heterosigositas atau variasi genetik [4].

Salah satu variasi genetik dan juga merupakan penanda genetik pada manusia adalah kemampuan dalam mengecap rasa pahit terhadap Phenylthiocarbamide (PTC) [5]. Penggunaan PTC dilakukan untuk mengamati variasi genetik atau keragaman genetik suatu populasi karena relatif mudah dikerjakan, akurat, dan mampu menggambarkan sifat yang muncul dari sifat gen autosomal resesif yang dapat diwariskan [6] [7]. Setiap manusia akan merespon PTC dengan rasa yang berbeda, beberapa orang dapat merasakan pahit dan lainnya tidak merasakan pahit. Golongan manusia yang dapat merespon PTC disebut sebagai taster (pengecap) dan yang tidak dapat merasakannya disebut non-taster (buta kecap) [2].

Peningkatan homosigositas dampak dari perkawinan endogami dapat meningkatkan ekspresi suatu kelainan genetik. Buta warna adalah salah satu gangguan penglihatan warna yang umumnya disebabkan oleh faktor genetik [8]. Buta warna disebabkan oleh ketidakmampuan sel-sel kerucut mata untuk menangkap suatu spektrum warna tertentu. Buta warna yang lebih sering ditemukan adalah buta warna partial merah hijau dibandingkan dengan buta warna total [9]. Terdapat variasi prevalensi buta warna merah-hijau (red-green colour blindness) pada ras, suku, dan kelompok etnis [10]. Prevalensi buta warna pada umumnya pada laki-laki lebih tinggi dibandingkan dengan perempuan, pada pia $8 \%$ dan perempuan $0,4 \%[11]$.

\section{METODE PENELITIAN}

Prosedur penelitian terdiri atas pengambilan sampel, pengambilan data, dan analisis data. Pengambilan sampel sesuai dengan prosedur pada Ethical clearance nomor 1225/UN25.8/KEPK/DL/2021. Sampel yang digunakan sebanyak 314 orang yang dipilih secara acak. Proses pengambilan sampel dilakukan secara acak. Pembuatan larutan PTC dengan cara melarutkan
1300 mg kristal PTC ke dalam 1 L akuades sebagai larutan no.1 sebagai larutan dengan konsentrasi tertinggi. Larutan no.1 diencerkan sebanyak 50\% untuk digunakan sebagai larutan no. 2 dan seterusnya hingga didapatkan larutan no.13 (0,32 mg/L) sebagai larutan dengan konsentrasi terendah [12].

Deteksi kemampuan mengecap PTC dilakukan dengan pemberian larutan PTC pada cotton buds ke lidah responden selama 5-10 detik. Responden diminta untuk menginterpretasikan rasa dari larutan PTC. Apabila responden merasakan rasa pahit dari PTC maka responden dikategorikan sebagai taster. Apabila responden tidak merasakan rasa pahit dari larutan PTC no.13, maka responden dikategorikan sebagai non taster [13].

Deteksi buta warna dilakukan menggunakan Ishihara plate test, dengan membaca dari plate 1 sampai dengan plate 14, dan diberi waktu untuk membaca selama 5-7 detik disetiap plate-nya. Penentuan probandus dikategorikan normal atau buta warna berdasarkan jumlah total plate yang dapat dibaca oleh probandus. Jika probandus dapat membaca 8 plate atau lebih maka probandus memilki penglihatan yang normal. Apabila probandus hanya dapat membaca 7 plate atau kurang maka dianggap buta warna [14].

Analisis data yang dilakukan meliputi prevalensi taster dan non taster, prevalensi buta warna, frekuensi alel taster dan non taster serta buta warna, serta melakukan analisis pedegree pada keluarga non taster dan buta warna

Persentase pengecap (taster), buta kecap (non taster) dan buta warna dapat dihitung dengan rumus sebagai berikut :

$$
X=a / n \times 100 \%
$$

keterangan:

a : jumlah sampel taster/no taster/buta warna

$\mathrm{n}$ : total sampel

Penentuan frekuensi alel taster (T) dan non taster $(\mathrm{t})$ diketahui menggunakan persamaan Hardy-Weinberg:

$$
\begin{aligned}
& (p+q)^{2}=1 \\
& p^{2}+2 p q+q^{2}=1 \\
& q=\sqrt{q^{2}} \\
& p=1-q
\end{aligned}
$$

keterangan:

$$
\mathrm{p}=\text { frekuensi alel dominan }(\mathrm{T})
$$$$
\mathrm{q}=\text { frekuensi alel resesif }(\mathrm{t})
$$ 
Frekuensi alel buta warna dan normal laki-laki diketahui menggunakan rumus:

$$
\begin{aligned}
& c=\frac{\% f \quad b \quad w}{\mathrm{C}}=1-\mathrm{c}
\end{aligned}
$$

Frekuensi alel buta warna dan normal perempuan diketahui menggunakan rumus:

$$
\begin{aligned}
& c=\frac{\sqrt{\% f} \quad b \quad w}{C}=1-c
\end{aligned}
$$

Frekuensi alel buta warna dan normal laki-laki dan peempuan diketahui menggunakan rumus:

$$
\begin{aligned}
& c=\frac{1}{3} \times c(l c-l c)+\frac{2}{3} \times c(p \iota) \\
& \mathrm{C}=1-\mathrm{c}
\end{aligned}
$$

\section{HASIL DAN PEMBAHASAN}

Hasil penelitian terhadap kemampuan mengecap PTC pada populasi suku Tengger dapat ditunjukkan pada Tabel 1.

Tabel 1.Distribusi fenotip taster dan non taster

\begin{tabular}{cccccccc}
\hline \multirow{2}{*}{ Fenotip } & \multicolumn{3}{c}{ Jenis Kelamin } & \multicolumn{2}{c}{ Jumlah } \\
\cline { 2 - 5 } & \multicolumn{2}{c}{ Laki- Laki } & \multicolumn{2}{c}{ Perempuan } & & \multicolumn{2}{c}{ Sampel } \\
\cline { 2 - 6 } & $\mathrm{n}$ & $\%$ & $\mathrm{n}$ & $\%$ & $\mathrm{n}$ & $\%$ \\
\hline Taster & 140 & $96,6 \%$ & 168 & $99,4 \%$ & 308 & $98,1 \%$ \\
Non & 5 & $3,4 \%$ & 1 & $0,6 \%$ & 6 & $1,9 \%$ \\
taster & & & & & & \\
Total & 145 & $100 \%$ & 169 & $100 \%$ & 314 & $100 \%$ \\
\hline
\end{tabular}

Persentase fenotipe taster adalah 98,1\% dan non taster sebanyak 1,9\%. Hasil penelitian ini menunjukkan persentase non taster pada suku Tengger lebih rendah dari pada penelitian sebelumnya yang telah dilakukan oleh Maharani pada tahun 2005 dengan persentase non taster lebih tinggi yaitu 10,4\%. Hal ini diduga pada tahun 2005 penduduk suku Tengger banyak mengkonsumsi makanan dan minuman panas serta merokok untuk mengatasi hawa dingin pada pada saat itu. Non taster bisa terjadi jika seseorang banyak mengkonsumsi makanan dan minuman panas setiap hari sehingga dapat mempengaruhi kepekaan lidahnya [16]. Sedangkan dari hasil penelitian pada suku Osing Banyuwangi menunjukkan persentase fenotip non taster 7,48\% [17]. Pada Tabel 2 frekuensi untuk non taster suku tengger pada laki-laki 3,4\% sedangkan pada perempuan $0,6 \%$. Hal ini menunjukkan bahwa perempuan suku Tengger memiliki kecenderungan lebih sensitif merasakan pahit PTC dibandingkan lakilaki dikarenakan kerapatan papila yang terdapat pada perempuan lebih tinggi daripada laki-laki [18]. Hasil perhitungan dari frekuensi alel dominan taster (T) dan alel resesif non taster $(\mathrm{t})$ dapat dilihat pada Tabel 2 . Frekuensi alel taster ( $\mathrm{T}$ ) lebih tinggi daripada alel non taster $(\mathrm{t})$. Hal ini menunjukkan jika alel taster (T) adalah dominan dan alel non taster ( $\mathrm{t}$ ) bersifat resesif [19].

Tabel 2. Frekuensi alel dominan (T) dan resesif ( $\mathrm{t}$ )

\begin{tabular}{ccccccc}
\hline \multirow{2}{*}{ Alel } & \multicolumn{4}{c}{ Jenis kelamin } & \multicolumn{2}{l}{ Total } \\
\cline { 2 - 5 } & \multicolumn{2}{c}{ Laki-laki } & \multicolumn{2}{c}{ Perempuan } & & \\
\cline { 2 - 5 } & $\mathrm{N}$ & Frek & $\mathrm{n}$ & Frek & $\mathrm{n}$ & Frek \\
\hline $\mathrm{T}$ & 140 & 0,81 & 168 & 0,92 & 308 & 0,86 \\
$\mathrm{t}$ & 5 & 0,19 & 1 & 0,08 & 6 & 0,14 \\
Jumlah & 145 & 1,00 & 169 & 1,00 & 314 & 1,00 \\
\hline
\end{tabular}

Kemampuan mengecap PTC adalah salah satu contoh sifat yang diwariskan orang tua kepada keturunannya [20]. Pewarisan sifat tersebut ditentukan oleh gen autosomal dominan T. Genotip TT atau Tt untuk seseorang yang dapat merasakan PTC (taster) dan genotip tt orang yang tidak bisa merasakan PTC atau buta kecap (non-taster) [21].

Dari hasil pemeriksaan buta warna pada populasi Suku Tengger di Desa Ranupani didapatkan hasil prevalensi buta warna sebesar 0,63\% sedangkan prevalensi orang normal adalah 99,37\%. Berdasarkan hasil tersebut nilai prevalensi buta warna pada suku Tengger lebih kecil dibandingkan dengan prevalensi buta warna di Indonesia (0,7\%) [22]. Hasil prevalensi buta warna dan normal pada suku Tengger dapat dilihat pada Tabel 3. Prevalensi buta warna pada pria menunjukkan angka yang lebih tinggi dibandingkan wanita. Hal ini disebabkan buta warna merupakan kelainan genetik yang dibawa oleh kromosom X (sex linked) [9]. Buta warna merupakan sifat bawaan resesif yang diturunkan secara genetik dan kebanyakan terjadi pada laki-laki. Laki-laki hanya memiliki satu kromosom $\mathrm{X}$ dan tidak dikenal istilah dominan maupun resesif sehingga sifat-sifat lebih mudah terekspresi [23].

.Frekuensi alel buta warna dan normal pada suku Tengger dapat ditunjukkan pada Tabel 4. Frekuensi alel buta warna sebesar 0,004 dan alel normal adalah 0,996. Berdasarkan data tersebut dapat diketahui bahwa frekuensi alel buta warna pada suku Tengger $(0,013)$ lebih kecil dibandingkan frekuensi alel buta 
warna pada India Utara $(0,087)$, frekuensi alel buta warna di Mughal $(0,05)$, dan pada siswa SMA di Jember $(0,09)$ [9], [24].

Tabel 3. Prevalensi buta warna dan normal

\begin{tabular}{ccccccc}
\hline \multirow{2}{*}{ Fenotip } & \multicolumn{2}{c}{ Laki-laki } & \multicolumn{2}{c}{ Perempuan } & \multicolumn{2}{c}{ Total } \\
\cline { 2 - 8 } & $\mathrm{n}$ & $\%$ & $\mathrm{n}$ & $\%$ & $\mathrm{n}$ & $\%$ \\
\hline ButaWarna & 2 & 1,29 & 0 & 0 & 2 & 0,63 \\
Normal & 153 & 98,71 & 159 & 100 & 312 & 99,37 \\
Total & 155 & 100 & 159 & 100 & 314 & 100 \\
\hline
\end{tabular}

Tabel 4. Frekuensi alel buta warna dan normal

\begin{tabular}{cccc}
\hline Fenotip & Laki-laki & Perempuan & Frekuensi Alel \\
\hline $\begin{array}{c}\text { Buta Warna } \\
\text { (c) }\end{array}$ & 0,013 & 0 & 0,004 \\
$\begin{array}{c}\text { Normal } \\
\text { (c) }\end{array}$ & 0,987 & 1 & 0,996 \\
Total & 1 & 1 & 1 \\
\hline
\end{tabular}

Hasil analisis diagram silsilah pada keluarga non taster dapat ditunjukkan pada Gambar 1 sedangkan keluarga penderita buta warna pada Gambar 2.

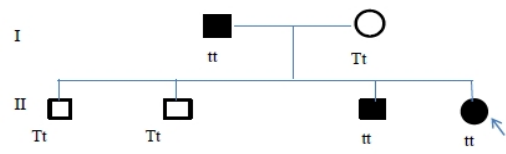

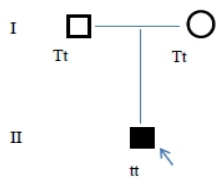

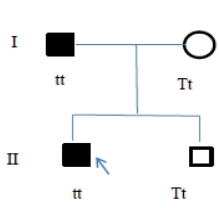

(c)

Gambar 1. Diagram silsilah keluarga non taster

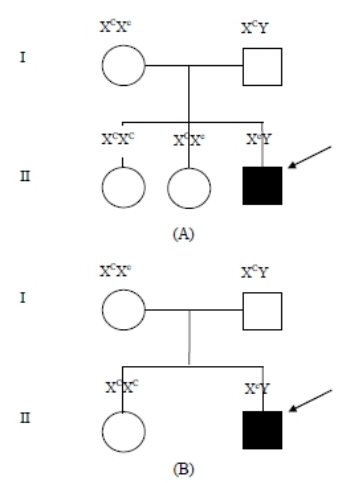

Gambar 2. Diagram silsilah keluarga buta warna

Pada keluarga (a) Gambar 1, orang tua individu non taster ( generasi I) teridentifikasi ayah sebagai non taster (tt) dan ibu adalah taster dengan genotip Tt. Mereka melahirkan 4 orang anak 2 anak merupakan individu non taster $(\mathrm{tt})$ yaitu laki-laki dan perempuan serta 2 anak perempuan normal atau taster ( $\mathrm{Tt}$ ). Pada keluarga (b) menunjukkan bahwa orang tua responden (generasi I) memiliki sifat taster, sehingga dipastikan bahwa genotip keduanya adalah heterosigot $(\mathrm{Tt})$. Keturunan mereka seorang anak laki-laki non taster (tt). Pada keluarga (c) menunjukkan orang tua responden (generasi I) Bapak bersifat non taster (tt) dan ibu adalah taster heterosigot $(\mathrm{Tt})$. Keturunan pasangan tersebut adalah laki-laki non taster (tt) dan perempuan taster heterosigot $(\mathrm{Tt})$.

Hasil analisis pedegree pada keluarga populasi Suku Tengger terdapat 2 orang pria penderita buta warna. Dari hasil pengujian tes Ishihara didapatkan bahwa pada pria 1 dikategorikan sebagai penderita buta warna karena hanya dapat membaca 7 plate, sedangkan pada pria 2 dikategorikan sebagai penderita buta warna karena hanya dapat membaca 5 plate. Pada Gambar 2 diagram silsilah 1 (A) seorang pria memiliki 2 orang saudara kandung dan keduanya adalah wanita. Pada gambar 2 diagram silsilah 2 (B) seorang pria memiliki 1 orang saudara kandung wanita. Dari kedua kasus penderita buta warna tersebut menunjukkan bahwa ibu dari mereka adalah carrier.

\section{KESIMPULAN}

Berdasarkan hasil penelitian yang telah dilakukan maka, prevalensi taster dan non taster pada sukuTengger desa Ranupani, Senduro, Lumajang berturut-turut adalah $98,1 \%$ dan 1,9\%. Sedangkan prevalensi buta warna adalah sebesar $0,63 \%$ orang normal 99,37\%. Frekuensi alel dominan taster $(\mathrm{T})$ dan alel resesif non taster $(\mathrm{t})$ berturut-turut adalah 0,86 dan 0,14. Frekuensi alel buta warna adalah 0,013 sedangkan frekuensi alel pada orang normal sebesar 0,987. Hasil analisis pedigree menunjukkan bahwa individu non taster yang ditemukan pada populasi suku Tengger dilahirkan dari pasangan taster heterozigot ( $\mathrm{Tt}$ ) atau hasil perkawinan non taster (tt) dengan taster heterozigotik ( $\mathrm{Tt}$ ). Analisis pedegree pada keluarga buta warna menunjukkan bahwa gen buta warna diwariskan secara bersilang dari yaitu ibu ke anak laki-laki.

\section{UCAPAN TERIMA KASIH}

Penulis mengucapkan terimakasih kepada perangkat Desa Ranupani, Kecamatan Senduro, Kabupaten Lumajang yang telah membantu 
pelaksanaan penelitian ini serta penduduk desa setempat yang telah bersedia menjadi probandus penelitian.

\section{DAFTAR PUSTAKA}

[1] O. H. Nurcahono, Harmonisasi Masyarakat Adat Suku Tengger (Analisis Keberadaan Modal Sosial pada Proses Harmonisasi pada Masayarakat Adat Suku Tengger, Desa Tosari, Pasuruan, Jawa Timur). Sosiologi, vol. 2, no. 1, pp. 1-12, 2018.

[2] R. D. Setiani, and G. Akhmad, Dukun Pandhita dan Pelestarian Budaya Lokal. Entitas Sosiologi, vol. 8, no. 2, 2019.

[3] A. A. Kusumadinata, Proses Enkulturasi dalam Budaya Entas-Entas, Praswala Gara, dan Pujan Kapat (Sistem Sosial Lokal: Antar Etnis Kabupaten Probolinggo). Komunikatio, vol.1, no. 1, pp. 17-29, 2015.

[4] J. Glinka, Model Perkawinan dan Dampak Biologisnya dalam Populasi, ed "Manusia Makhluk Sosial Biologis" Surabaya: Airlangga University Press. pp 148-162, 2008.

[5] I. A. J. Thanoon, S. K Al-Dabbagh., I. H. Mahmood and H. AS. Abdul-Jabbar, Phenylthiocarbamide Perception in Epileptic Patients on Carbamazepine Therapy. Irq J Pharm, vol. 11, no. 1, pp. 1-5, 2011.

[6] S. G. Alimba, O. A. Khalid, and O. O. Bola, Prevalence and Gene Frequencies og Phenylthiocarbamide (PTC) Taste Sensitivity, ABO and Rhesus Factor (Rh) Blood Groups, and Haemoglobin Variants Among a Nigerian Population, Medical Human Genetics, vol. 11, no. 2, pp. 153-158, 2010.

[7] Hussain, A. Shah, and M. Afzal, Distribution of Sensory Taste Thresholds for Phenylthiocarbamide (PTC) Taste Ability in Indian Muslim kho Populations, Egypt. J., Med. Hum. Genet, vol. 14, no. 4, pp. 367-373, 2013.

[8] H. S. Ilyas, Ilmu Penyakit Mata untuk Dokter Umum dan Mahasiswa Kedokteran Edisi 2, Perhimpunan Dokter Spesialis Mata Indonesia. Jakarta: Sagung Seto, 2004.

[9] M. Fareed, M. A. Anwar, and M. Afzal, Prevalence and Gene Frequency of Color Vision Impairments Among Children of Six Populations From North Indian Region, Genes and Diseases, vol. 2, no. 2, pp. 211218, 2015

[10] N. W. Karolina, M. Pharmawati, and I. Setyawati, Prevalensi dan frekuensi gen buta warna siswa sekolah dasar di Kabupaten Badung, Bali, Indonesia. Jurnal Biologi Udayana, vol. 23, no. 2, pp. 42, 2019.

[11] J. Brich, Diagnosis of Defective Colour Vision, Hongkong: Oxford Medical Publication, 1993.
[12] H. Harris, and H. Kalmus, The Measurment of Taste Sensitivity to Phenylthourea (PTC). Annals of Human Genetics, vol. 84, no. 3, pp. 24-31.

[13] M. A. Fareed, A. Shah., R. Hussain, L. Afsal, Genetic Study of Phenylthiocarbamide (PTC) Taste Perception Among Six Human Populations of Jammu and Kashmir (India), The Egyptian J of Med Hum Gen, vol. 13, pp. 161-166, 2012

[14] S. Ishihara, Ishihara's Test for Colour-Blindess. Tokyo: Kanehara \& CO., LTD, 1994.

[15] V. Filiptsova, I. A. Timoshyna., N. Y, Kobets., N. M. Kobets., I. S. Burlaka dan I. A. Hurko, The Population Structure of Ukraine in Relation to the Phenylthiocarbamide Sensivity, The Egyptian Journal of Medical Human Genetics, vol. 16, pp. 135-139, 2015.

[16] Maharani, N.D., Studi Kemampuan Mengecap PTC Pada Suku Tengger di Desa Ranupani Kecamatan Senduro-Lumajang, Skripsi. Jember: Universitas Jember, 2005.

[17] F. Indriani, S. W.athon, R. Oktarianti, Genetic Study of Phenylthiocarbamide (PTC) Taste Sensitivity In Population of The Osing in KemirenVillageBanyuwangi. BERKALA SAINSTEK, vol. 9, no. 1, pp. 1-5, 2021

[18] V. B. Duffy, and L. M. Bartoshuk, Food Acceptance and Genetic Variation in Taste, J Am Diet Assoc, vol. 100, pp. 647-655, 2000.

[19] S. Balemi, and E. Bakele, Variations in Tasting Phenylthiocarbamide (PTC) in Selected Individuals from Ethiopia: Implications for Human Health. Ethiopian Journal of Education and Sciences. vol. 15, no. 2, pp. 4555, 2020.

[20] C. Igbeneghu, T. B. Oluwatunbi., O. A. Aina and J. M. Olisekodiaka. Phenylthiocarbamide Taste Perception among HIVInfected Patients on Highly Active Antiretroviral Therapy. Medicine \& Medical Research, vol. 19 , no. 10, pp. 1-7.

[21] A. Griffiths, W. M. Gelbart., J. H Miller, and R. C Lewontin, Modern Genetic Analyis. New York : W H Freeman and Company, 1999.

[22] Kemenkes, Laporan Nasional Riskesdas 2007. Laporan Nasional 2007, pp. 1-384, 2007.

[23] T. T.Geletu, Manikan, and M. Tamiru, Identification of Colorblindness Among Selected Primary School Children in Hararghe Region, Eastern Ethiopia, Alexandria Journal of Medicine, vol. 54, pp. 327-330, 2018.

[24] A. D. Wulandari, S. Wathon, and R Oktarianti, Prevalensi Buta Warna Siswa Sekolah Menengah Atas di Kota Jember. BERKALA SAINSTEK, vol. 8, no. 4, pp. 102, 2020. 